Mobilizing the Public Sphere: Scandal, Political Culture, and the Signing of the Treaty of Amity and Commerce of 1778

\author{
Lauren Marie Wallace \\ Waxhaw, North Carolina
}

B.A., University of North Carolina at Chapel Hill, 2011

M.A. in Comparative and Transnational History, College of William and Mary, 2013

A Thesis presented to the Graduate Faculty

of the University of Virginia in Candidacy for the Degree of

Master of Arts

Corcoran Department of History

University of Virginia

May, 2014 
Mobilizing the Public Sphere: Scandal, Political Culture, and the Signing of the Treaty of Amity and Commerce of 1778

\section{Lauren Wallace}

In March of 1778 Silas Deane received orders from the Continental Congress to return home. After years of negotiating a treaty, Deane hardly knew how to respond to the request to leave France so soon after his long-awaited success. Only one month earlier, the American deputies in Paris - Silas Deane, Benjamin Franklin, and Arthur Lee - had successfully convinced the French government to declare public support for the fledgling American state with treaties of Amity and Commerce. Cognizant of the necessity of foreign aid to combat the might of the British Empire, the deputies had worked tirelessly to persuade a reluctant French ministry to openly court British retaliation by allying with the colonies engaged in revolt against their mother country. That March, however, the American government remained ignorant of the deputies' success. Instead, the Continental Congress saw only the vast expenditures and the woefully inadequate French soldiers of fortune to whom Deane had promised commissions in the continental army. When Deane boarded the ship to return to America he had no idea that he would be put on trial for war profiteering, his honor challenged and all but destroyed. ${ }^{1}$ Meanwhile, the French government feared the recall of one of the deputies was a sign of American reluctance to continue the fight for independence, challenging the image of America that the new government, the American deputies, and

\footnotetext{
${ }^{1}$ Later, throughout the course of the congressional debates, Arthur Lee and Silas Deane became embroiled in a public airing of grievances, with each accusing the other of undermining the negotiation of the FrancoAmerican Alliance. This paper, however, explores the French reaction to the news of Silas Deane's recall in 1778 rather than the trial of 1779. For more on the trial of Silas Deane, see Coy Hilton James, Silas Dean - Patriot or Traitor? (Michigan State University Press, 1975), 74-78.
} 
the media had fostered since the outbreak of hostilities. The road to alliance, however, had been rocky from the start and the French government and its official media were more than prepared to meet this newest challenge.

At the start of the rebellion, on April 19, 1775, British regulars clashed with colonial militiaman at a minor skirmish that would later be memorialized as the shot heard round the world. By May, the colonial press was hard at work demonizing the enemy with a battle cry of "Americans! Forever bear in mind the BATTLE of LEXINGTON!" ${ }^{2}$ Within months, news had crossed the Atlantic, and journalists in France quickly engaged in a vociferous debate over blame and the implications of a rebellion in the English colonies. Looking back following the upheavals of the eighteenth century, one French nobleman, Louis Philippe de Ségur ${ }^{3}$, articulated the attitude of his contemporaries when he wrote, "the first cannon shot, fired in that hemisphere, in deference of the standard of liberty, resounded throughout Europe, with the rapidity of lightening... Their daring courage electrified every mind, and excited universal admiration." ${ }^{4}$

This "daring courage" and lust for battle eventually began to permeate the hallowed halls of Versailles, the seat of one of the most powerful monarchies in Europe. The young Louis XVI, aided by his ministers, followed reports of the American drama with interest and a growing understanding that this rebellion was not simply another

\footnotetext{
${ }^{2}$ Isaiah Thomas, Massachusetts Spy 3 May 1775, 3:1 (accessed via America's Historical Newspapers).

${ }^{3}$ Louis Philippe de Ségur was a noble of the sword and historian who eventually wrote a memoir about his experiences in both the American Revolution and the French Revolution. Initially supportive of the French Revolution, Ségur later became disenchanted with the increased violence and the execution of prominent members of the old government. His memoirs and his historical publications attempt to explain how French society moved from peaceful questioning to outright rebellion.

${ }^{4}$ Count Louis Philippe de Ségur, Memoirs and Recollections of Count Louis Philippe de Ségur: Three Volumes in One, published 1824, ed. Harmon Tupper and Harry W. Nerhood (New York: Arno Press \& The New York Times, 1970), 75.
} 
colonial skirmish, but instead an event of great resonance and even greater ramifications for not only the fledgling American government and Britain, but also for the increasingly connected Atlantic world as a whole. The France of 1778 was by no means a republic, and the "public," insomuch as it can be called that, was more of a restricted group of intellectually involved individuals who, through social, political, and financial power, began to wield increasing influence in public affairs. France may have been an absolute monarchy, but the French state still maintained channels of communications with its nobility, clergy, and members of the upper echelons of the Third Estate. In order to launch a successful intervention into New World politics and military engagements, the French state needed the support of all segments of this growing public sphere - one that began to coalesce long before the French Revolution of 1789 .

Certainly the success of the American Revolution and the financial cost of French support contributed to the later upheavals in the established political system, but many French historians have traditionally been so blinded by the French Revolution that they have ceased to see the American Revolution as anything other than a prelude. This paper seeks to correct this assessment and engage with a historiographical movement that views French involvement in the American Revolution as not just a precursor to the French Revolution, but also as a period of momentous change and the beginnings of a decades long discussion over the practical application of Enlightenment ideas. Through an analysis of the connections between state desires and public action, this paper will argue that the signing of the Treaty of Amity and Commerce represents an important moment in the development of the public sphere as government officials began to understand the necessity of courting public approval before enacting state policies. 
The surrounding context of the Franco-American Alliance underscores the momentous nature of this treaty in the quest to understand the distinctiveness of the 1770s to the development of late Old Regime political culture. During the early years of the American conflict, from 1776 to 1778 , the French intellectual elite actively negotiated the link between Enlightenment ideas and policy. Intellectuals (i.e. self-declared philosophes) and government ministers drew on multiple cultural developments - their own classical educations, a burgeoning salon and discussion culture, growing interest in public affairs from a secular rather than religious position, and a desire for French greatness - without destroying the existing political system. The French government was highly influenced by this confluence of trends, becoming increasingly eager to use the idea of a balance of power to revive the image of French greatness and avoid succumbing to Anglophobia. The American Revolution offered the perfect moment to experiment with strategies for effecting this ideal through state policy and print culture.

Within the larger historiography analyzing France during the American Revolution, there exist three main categories of study: political culture, diplomacy, and biographical investigations. ${ }^{5}$ This paper argues for a reevaluation of this existing

\footnotetext{
${ }^{5}$ For the purposes of this paper, I have chosen to highlight a few of the contributions to this literature in the body of the work. However, the English-language historiography of France in the eighteenth century is extensive and highly specialized. For instance, there is a rich literature that looks at the social and political situation in France leading up to the French Revolution, as well as the history of Franco-American relations. For more information on the social causes of the French Revolution and the aristocracy, see William Doyle, Aristocracy and its Enemies in the Age of Revolution (New York: Oxford University Press, 2009); William Doyle, Origins of the French Revolution. (New York: Oxford University Press, 1988); and Jay M. Smith, The Culture of Merit: Nobility, Royal Service, and the Making of Absolute Monarchy in France, 1600-1789 (Ann Arbor: The University of Michigan Press, 1996). For more on the connection between American and France, see Robert Darnton, George Washington's False Teeth: An Unconventional Guide to the Eighteenth Century (New York: W. W. Norton \& Company, Inc., 2003); and Susan Dunn, Sister Revolutions: French Lightening, American Light (New York: Faber and Faber, Inc., 1999). For more on the relationship between America and France from a trans-Atlantic perspective see, among others, Jack P. Greene and Philip D. Morgan, Atlantic History: A Critical Appraisal (Oxford and New York: Oxford University Press, 2009); Wim Klooster, Revolutions in the Atlantic World: A Comparative History (New York: New York University Press, 2009); Karen Ordahl Kupperman, The Atlantic in World History
} 
literature and calls for synthesis. Typically, historians consider older historiographical contributions as examples of outdated methodologies and as preliminary efforts at piecing together stories without the benefit of more recently discovered source material. However, with regard to studies of the American Revolution, it would behoove historians to reexamine these early forays into Franco-American revolutionary historiography. For instance, as early as 1911, James Breck Perkins argued for an exploration of the convergence of the public sphere and policy making when investigating the role of France in the American Revolution. ${ }^{6}$ However, despite Perkins' novel ideas, he became trapped in a teleological argument that saw France in 1778 as analogous to France in 1789 , eliding a general sense of class conflict to include later struggles between the different estates into the history of the American Revolution. Tensions between the various French estates did exist in 1778, but more often than not intra-estate conflicts were the real source of tension. ${ }^{7}$ This is but one example of historians wrongly attempting to incorporate the American Revolution into their narratives about the French Revolution of 1789 , eliding ten years of incremental change. Despite great strides in the past few years, many French historians continue to treat the American Revolution as a passing incident in larger histories of the upheaval and novelty of the French Revolution.

If earlier French historians correctly accounted for the public sphere while

(Oxford and New York: Oxford University Press, 2012); and John K. Thornton, A Cultural History of the Atlantic World, 1250-1820 (Cambridge and New York: Cambridge University Press, 2012).

${ }^{6}$ James Breck Perkins, France in the American Revolution (Boston and New York: Houghton Mifflin Company, 1911), 204.

${ }^{7}$ In fact, many historians of the newer schools argue that prior to the publication of Sieyes' "What is the Third Estate?" this division between the first two estates and the Third Estate paled in comparison to the divisions between rural and urban peoples. For more information on the nobility and the tensions between different segments of the noble population, see Guy Chaussinand-Nogaret, The French Nobility in the Eighteenth Century, trans. William Doyle (Cambridge, London, New York and Melbourne: Cambridge University Press, 1985) and Patrice Higonnet, Class, Ideology, and the Rights of Nobles During the French Revolution (Oxford: Clarendon Press, 1981). 
condensing the timeline of the late eighteenth century, many later diplomatic historians, such as Jonathan R. Dull, have ignored the impact of social history entirely. In his $A$ Diplomatic History of the American Revolution, for example, Dull fails to account for efforts at mobilizing the public sphere, choosing instead to promote a great man hypothesis that obscures the reality of the situation in France at the time of the American Revolution. ${ }^{8}$ For Dull, the French Minister of Foreign Affairs, the Comte de Vergennes, alone was responsible for policy making during the negotiation of Treaties of Commerce and Amity; the more general educated population is treated as something of an afterthought. The picture of the government of Vergennes and Louis XVI is similarly one of disinterested high politics. This picture conflicts with that presented more recently in scholarship relating to the development of the French press. The contributions of Jack Censer, Daniel Roche, Robert Darnton, and Jeremy Popkin directly undermine this simplistic account of French political life. ${ }^{9}$ Historians would be better served subscribing to Lynn Hunt's embrace of the study of political culture. ${ }^{10}$ In particular, the study of print culture in eighteenth-century France highlights the growth of a public sphere and the rise of wider popular participation in the crafting of state strategies. David Bell points out that the late Old Regime press served as an expression of government

\footnotetext{
8 Jonathan R. Dull, A Diplomatic History of the American Revolution (New Haven and London: Yale University Press, 1985), 75-103.

${ }^{9}$ See Jack R. Censer, The French Press in the Age of Enlightenment (London and New York: Routledge, 1994); Jeremy D. Popkin, News and Politics in the Age of Revolution: Jean Luzac's Gazette de Leyde, (Ithaca: Cornell University Press, 1989); Jeremy D. Popkin and Bernadette Fort, The Mémoires Secrets and the Culture of Publicity in Eighteenth-Century France (Oxford: Voltaire Foundation, 1998); Roger Chartier, The Cultural Origins of the French Revolution, trans. Lydia G. Cochrane (Durham and London: Duke University Press, 1991); Robert Darnton, The Literary Underground of the Old Regime (Cambridge and London: Harvard University Press, 1982); and Robert Darnton and Daniel Roche, Revolution in Print: The Press in France, 1775-1800 (Berkeley, Los Angeles, and London: University of California Press, 1989).

${ }^{10}$ Lynn Hunt, Politics, Culture, and Class in the French Revolution (Berkley and Los Angeles: University of California Press, 1984).
} 
policy intending to mobilize public opinion in favor of the war effort. ${ }^{11}$

Finally, as case studies of the lives and ideas of single individuals, the genre of biography is inherently tightly focused. It is also highly susceptible to the great man theory of history. Each author seeks to cast his or her protagonist in the role of hero and often, despite good intentions, creates the impression his or her subject is the main driving force behind policy-making. For instance, in his study of Silas Deane entitled Silas Dean: Patriot of Traitor?, Coy Hilton James' desire to exonerate Deane of wrong doing produces the distinct impression that men such as Vergennes and Benjamin Franklin were but supporting cast members in an international melodrama, with the public sphere virtually nonexistent. This is not to say that James' insights, and particularly his analysis of the correspondence of the American deputies, do not amount to a valid contribution to the historiography. Historians, however, should continue to be wary of the attachment biographers often develop for the subject of their studies.

By exploring the entanglements of three distinct entities - the diplomats, the foreign ministry, and the public sphere - this paper engages in a case study of the events surrounding the signing of the Franco-American Alliance of 1778 in order to make broader claims about the nature of diplomacy and about diplomats' conscious manipulation of the developing public sphere in eighteenth-century France. This particular moment in French history speaks to broader issues of government control of information, the development of the press, the crystallization of societal values and norms, as well as the involvement of noncombatants in the war effort. The reciprocal relationship that developed as a result of the Franco-American alliance had an impact not

\footnotetext{
${ }^{11}$ David Bell, The Cult of the Nation in France: Inventing Nationalism, 1680-1800 (Cambridge and London: Harvard University Press, 2001), 99.
} 
only on the American Continental Congress, but also on French policymaking. The 1778 Treaty of Amity and Commerce represented years of negotiation and underscored the connectedness of the political cultures of France and America in the late eighteenth century. The American Revolution gave French intellectuals and government officials an opportunity to put Enlightenment ideas and eighteenth-century innovations into practice within the same geographic and temporal space as those individuals whom they saw as already embodying those new principles.

In order to understand the eventual diplomatic, military, and social relationship that developed between France and America after 1776, it is first necessary to understand the motivations for both the French intellectual sphere's interest in the activities of the English colonies and the policies that developed as a result of these intellectual impulses. French engagement with the Atlantic World included both commercial and intellectual endeavors. Many historians have discussed the ramifications of the Seven Years War and the loss of French colonial possessions, citing both the financial and emotional impact of the losses as one of the main impetuses to support the American cause. However, this prevailing explanation obscures the complexities of the historical memory and intellectual movements present in France in the 1770s. Certainly, French government ministers recognized the benefits of gaining a new trading partner and the possibility of protecting trade in the West Indies, but the target audiences of the French gazettes of the 1770s were also part of a burgeoning salon culture that included those interested in the intellectual ramifications of state fiscal policy. ${ }^{12}$ Only by acknowledging the many facets

\footnotetext{
${ }^{12}$ For more information about the potential trade benefits, see Orville T. Murphy, "The View From Versailles: Charles Gravier Comte de Vergennes's Perceptions of the American Revolution," in Diplomacy and Revolution: The Franco-American Alliance of 1778, ed. Ronald Hoffman and Peter J. Albert
} 
of this interest can historians hope to understand the resulting literature, both public and private, surrounding the French Alliance.

Secretary of State and Minister of Foreign Affairs Charles Gravier, Comte de Vergennes' personal motivations reflected the interests of the French state, specifically a hope to shift the balance of power in Europe to produce an elevated position for France. ${ }^{13}$ Traditionally, when discussing the balance of power, historians depict the eighteenth century as a long stalemate where, in an effort to avoid total war, great powers often hesitated to provoke violence or to challenge the trade of another perceived equal. However, James Sofka rightly advocates for a reevaluation of this misconception, arguing that the balance of power in the eighteenth century was an undesirable anomaly rather than an actively pursued strategy. Citing Hume, Sofka suggests that when talking about a balance of power, early modern intellectuals really meant a balance of trade. ${ }^{14}$ It stands to reason that Sofka is correct, because in a society where a monopoly was sought after, why would early modern governments desire the protection of hostile neighbors' livelihoods? Dull and Murphy echo this sentiment, arguing Vergennes sought to place France in a superior political and economic position rather than a balanced one. ${ }^{15}$ In this way, the American Revolution can be seen as part of a larger eighteenth-century battle

(Charlottesville: Published for the United States Capitol Historical Society by the University Press of Virginia, 1981), 116.

${ }^{13}$ For more information about le Comte de Vergennes see Orville T. Murphy, Charles Gravier Comte de Vergennes: French Diplomacy in the Age of Revolution, 1719-1787 (Albany: State University of New York Press, 1982).

${ }^{14}$ James R. Sofka, “The Eighteenth Century International System: Parity or Primacy?” Review of International Studies, 27 (2001): 154.

${ }^{15}$ Jonathan R. Dull, A Diplomatic History of the American Revolution (New Haven and London: Yale University Press, 1985), 59; and Murphy, "The View From Versailles," 114. 
for political and economic supremacy in the Atlantic by the various colonial powers. ${ }^{16}$

However, in order to accomplish this goal, Vergennes needed a war, specifically

one involving England. Competition with England was nothing new, but throughout the

eighteenth century a series of escalations of political tension had erupted into military

conflicts. The humiliating defeat in the Seven Years War upset France's standing in the

international community and ushered in a new era of competition between England and

France in which colonial possessions were pawns in larger imperial struggles. ${ }^{17}$ This

desire to reset the balance of trade was finally reflected in Vergennes' inquiries of the

American deputies. Silas Deane wrote to the Secret Committee of Congress in August of

1776 that "[Vergennes] then asked me many questions with respect to the Colonies; but

what he seemed most to want to be assured of, was their ability to subsist without their

fisheries, and under the interruption of their commerce."18 Prior to the arrival of the

deputies, the Gazette de France contained numerous references to the interruption of

\footnotetext{
${ }^{16}$ For more on the role of protection of trade and power in the crafting of strategy in the American Revolution, see Andrew Jackson O'Shaughnessy, An Empire Divided: The American Revolution and the Caribbean (Philadelphia: University of Pennsylvania Press, 2000).

${ }^{17}$ Competition in the Atlantic was nothing new, but the late eighteenth century saw an escalation of conflict and a reevaluation of the importance of particular colonial possessions. At the close of the Seven Years War, for instance, the French government was forced to decide what sort of empire would be pursued: a land empire in North America or an island empire in the Caribbean. Ultimately, France decided to protect profitable sugar colonies rather than retain possession of Canada. Britain, meanwhile, took possession of most of North America in an effort to establish a great continental empire. In addition to witnessing full scale military conflict, throughout the seventeenth and eighteenth centuries the islands in the Caribbean constantly changed hands as various colonial powers sought access to valuable trade commodities, including raw materials, sugar, and other luxury items such as mahogany. Military resources were constantly diverted to the Caribbean in order to protect these island commodities, as one colonial power would often attempt to seize or sack a port in order to disrupt a rival's trade network. For more on colonial competition, see Jeremy Black, America or Europe?: British Foreign Policy, 1739-63 (London and Bristol: UCL Press, 1998); Helen Dewar, "Canada or Guadeloupe?: French and British Perceptions of Empire, 1760-1763," Canadian Historical Review 91, no. 4 (December 2010); Richard Dunn, Sugar and Slaves: The Rise of the Planter Class in the English West Indies, 1624-1713 (Chapel Hill: The University of North Carolina Press, 1972); Andrew Jackson O'Shaughnessy, An Empire Divided: The American Revolution and the British Caribbean (Philadelphia: University of Pennsylvania Press, 2000); and David Watts, The West Indies: Patterns of Development, Culture and Environmental Change since 1492 (Cambridge and New York: Cambridge University Press, 1987).

${ }^{18}$ Silas Dean to the Secret Committee of Congress, Paris, 18 August 1776 in The Deane Papers, Vol. I, 1774-1777 (New York: New York Historical Society, 1886), 200.
} 
trade caused by the hostilities, including various reports regarding the Newfoundland fisheries and the prohibition of access to residents of the thirteen colonies. ${ }^{19}$ This coverage in the government-sanctioned journal, along with Vergennes' own comments, suggests the French monarchy's preoccupation with trade and its accompanying perception of power when approaching the American Revolution. Despite Vergennes’ own fixation on trade, however, the minster was aware of other potential motivations held by the various intellectuals who read the journals. Other articles featured in the two main official gazettes, the Gazette de France and Affaires de l'Angleterre et de l'Amérique often referenced British brutality, the lack of respect for various perceived inherent natural rights, and the general barbarism of the British army. These other moments of propaganda will be discussed in greater detail later in this essay.

The 1776 Declaration of Independence and the arrival of American deputies in Paris necessitated a formal response, rather than merely contemplation, on the part of the French ministry, and thus began a delicate political dance that continued until the signing of the treaties of Amity and Commerce in $1778 .{ }^{20}$ Vergennes and Louis XVI privately supported the American cause from the beginning, but publically chose to be more circumspect, deciding to wait for optimal terms prior to entering into any legal or other official commitment with the newly formed United States. ${ }^{21}$ Vergennes willingly

\footnotetext{
${ }^{19}$ Gazette de France, 31 March 1775 and Gazette de France, 3 April 1775.

${ }^{20}$ For David Armitage's argument that the Declaration of Independence was necessary for the solicitation of foreign aid, see Armitage, The Declaration of Independence: A Global History (Cambridge and London: Harvard University Press, 2007).

${ }^{21}$ There has been some debate in the scholarly community regarding the position of Louis XVI on the American War of Independence. Much of the older historiography depicts Vergennes pulling a reluctant king into conflict, but newer works and the publication of additional papers projects have shown Louis to be an early supporter of the American revolutionaries. Like Vergennes, Louis XVI sought to provoke an English offensive rather than openly declare support for the Americans. See in particular John Hardman and Munroe Price, Louis XVI and the comte de Vergennes: correspondence 1774-1787, in Studies on Voltaire and the Eighteenth Century 364 (Oxford: Voltaire Foundation, 1998); Dull, A Diplomatic History
} 
complimented the arriving deputies, and particularly Franklin, "on his celebrity, his knowledge, and the honor of seeing so distinguished a person, on an Errand of the first consequence," but, in the words of Arthur Lee, Vergennes also conveyed "trembling hesitation., ${ }^{22}$ This cautious attitude permeated all future interactions, including negotiating the Franco-American Alliance or "Treaty of Amity and Commerce" and the subsequent scandal that erupted following Silas Deane's recall to face charges before the Continental Congress.

The ministers and the reading public in France were highly influenced by the strong personalities and public personas of the deputies sent to France on behalf of the fledgling American government. In 1776, following the official declaration of rebellion, the Secret Committee of Correspondence had nominated three deputies to negotiate on behalf of the newly formed American government: Benjamin Franklin, Silas Deane, and Arthur Lee. Their instructions were "to make immediate application to Monsieur de Vergennes, Minister des Affaires Etrangeres, either personally or by letter ....acquainting him that you are in France upon business of the American Congress...having something to communicate to him, that may be mutually beneficial to France and the North American Colonies." ${ }^{23}$ The aims of these negotiations were to secure formal recognition of the United States of America, to elicit aid (both financial and military assistance), and to establish a mutually beneficial trade agreement. While open to the agreement, as previously stated, Vergennes and Louis XVI hoped to secure the most favorable terms

of the American Revolution; and Louis XVI, King of France, "Réflexions," in The Marquis de La Fayette in the American Revolution, with some account of the attitude of France toward the War of Independence, Volume 1 (Freeport: Books for Libraries Press, 1971).

${ }^{22}$ Arthur Lee to the Committee of Secret Correspondence, 31 December 1776, quoted in Louis W. Potts, Arthur Lee: A Virtuous Revolutionary (Baton Rouge and London: Louisiana State University Press, 1981), 164.

${ }^{23}$ Secret Committee of Congress to Silas Deane, 3 March 1776, in The Deane Papers, 123-124. 
before committing officially sanctioned support. In the meantime, the deputies continued to showcase their personalities by attending salons, cultural engagements, and generally exploited French susceptibility to excitement over the revolutionary fervor.

Speaking of this time, Ségur wrote, “American deputies, Silas Deane and Arthur Lee, arrived in Paris and the celebrated Benjamin Franklin was soon after added to their number. It would be difficult to describe the eagerness and the delight with which these men, the agents of a people in a state of insurrection against their monarch, were received in France, in the bosom of an ancient monarchy." ${ }^{, 24}$ With this statement, Ségur selfdeprecatingly referred to an inherent paradox not yet visible to his contemporaries. But his statement still captures the air of excitement and anticipation that surrounded the American deputies in France.

The growing French interest in the American cause was due in no small part to the machinations and political genius of Benjamin Franklin. Many scholars have noted Franklin's larger-than-life presence in France during the late eighteenth century. Prior to his arrival, much of the educated elite already had some knowledge of Franklin as a result of both contemporary fascination with his scientific experiments and his eloquent defense of the American Colonies in the years leading up to the outbreak of war. ${ }^{25}$ Simon Schama characterizes this fascination as "Franklin Mania," noting Franklin was probably more recognizable on the streets of Paris and more likely to be mobbed than the king himself. ${ }^{26}$ Capitalizing on his immense authority, Franklin consciously conformed to French expectations of America, often projecting a unsophisticated, bumpkin image in

\footnotetext{
${ }^{24}$ Count Louis Philippe de Ségur, Memoirs and Recollections of Count Louis Philippe de Ségur, 101.

${ }^{25}$ R. R. Palmer, The Age of the Democratic Revolution: The Challenge (Princeton: Princeton University Press, 1959), 249.

${ }^{26}$ Simon Schama, Citizens: A Chronicle of the French Revolution (New York: Alfred A Knopf, 1989), 42.
} 
keeping with the French belief that America represented an unspoiled republican utopia. ${ }^{27}$ Ségur noted, "the almost rustic apparel, the plain but firm demeanor, the free and direct language of the envoys, whose antique simplicity of dress and appearance seemed to have introduced within our walls, in the midst of the effeminate and servile refinement of the eighteenth century, some sages contemporary with Plato, or republicans of the age of Cato and Fabius.",28

Additionally, Silas Deane also proved popular with French elite society. He quickly established a working relationship with Pierre-Augustin Caron de Beaumarchais, the famous playwright, who in turn began to furnish aid secretly to the Americans. With the approval of Vergennes, Deane and Beaumarchais established the Roderigue Hortalez Company, a front for smuggling munitions and money to the American insurgents. ${ }^{29}$ Deane's involvement ultimately caused fissures in the American deputies' relationships with one another since Arthur Lee resented Deane's role in the operation of the Roderigue Hortalez Company and the accompanying notoriety as an important aid. ${ }^{30}$ This association between Deane and Beaumarchais and the resulting tensions that developed with Arthur Lee had a marked impact on the French reaction to the Deane Scandal in 1778.

However, as the deputies negotiated with the French ministry, they often became

\footnotetext{
${ }^{27}$ Scholars have since noted Franklin's conscious manipulation of expectations to encapsulate the perceived incorruptibility of the Americas verses the spoiled and polluted luxury of Europe. When analyzing reactions in France to the American deputies and the aftermath of the Franco-American Alliance, it is important to keep these perceptions in mind. For more on the image of Benjamin Franklin in France see, among others, Schama, Citizens, $42-43$ and Palmer, The Age of the Democratic Revolution.

${ }^{28}$ Ségur, Memoirs and Recollections of Count Louis Philippe de Ségur, 101.

${ }^{29}$ See Dull, A Diplomatic History of the American Revolution, 93-94. For more on the role of Beaumarchais in the War for American Independence, see Harlow Giles Unger, Improbable Patriot: The Secret History of Monsieur de Beaumarchais, The French Playwright who Saved the American Revolution (Lebanon, N. H.: University Press of New England, 2011).

${ }^{30}$ See Potts, Arthur Lee, 158-159, 164, and 185-186.
} 
embroiled in misunderstandings with the French government as well. Specifically, confusion ensued about the overt use of French ports by American warships. While certainly secretly aiding America, France was reluctant to incite war with England directly. Instead, France hoped to subtly provoke England into declaring war so as to launch an offensive based on a violation of rights or sovereignty and to protect the neutrality pacts of other polities. As such, a flagrant disregard for French neutrality was unacceptable. This misstep by the American deputies raised tensions among the negotiators and necessitated a response in French journals since letters and other communications from British officials indicating increased British hostility had begun to circulate in France. ${ }^{31}$ Additionally, the repercussions of the shattering of the illusion of neutrality caused the French ministers and Louis XVI to question the deputies' abilities and commitment to a mutually beneficial alliance. Moreover, escalating conflict between Deane and Lee undermined the perception of unity that the American deputies hoped to project, forcing the French ministry to question the American Congress' willingness, not to mention ability, to see the conflict with England through after securing French aid. This caution and distrust impacted France's navigation of the scandal that began in March of $1778 .^{32}$

Within weeks of the signing of the alliance, tensions exploded between the three American deputies, resulting in the recall of Silas Deane to America to face charges of corruption. Lee and his supporters accused Deane of wasting money and of war

\footnotetext{
${ }^{31}$ For more information on this crisis, see Dull, A Diplomatic History of the American Revolution, 80-81. ${ }^{32}$ The signing of the treaty was a complex issue that has been debated by numerous scholars; see Dull, $A$ Diplomatic History of the American Revolution; Armitage, The Declaration of Independence; Palmer, The Age of the Democratic Revolution; Murphy, "The View From Versailles;" Potts, Arthur Lee; Coy Hilton James, Silas Deane: Patriot or Traitor? (Michigan State University Press, 1975); Perkins, France in the American Revolution; and Hoffman and Albert, Diplomacy and Revolution.
} 
profiteering. Over the years, various biographers and historians have attempted to clear Deane of these charges, but the general consensus now is that while he was probably innocent of the charges relating to finances, he had offered commissions to French officers without prior authorization. One prominent French nobleman, Ségur, remarked, "It was not concealed from us, by Sileas [sic] Deane and Arthur Lee, that the assistance of some well informed officers would be at once acceptable and useful to their country. They even went so far as to say that they were authorized to promise to such as were inclined to embrace their cause, military rank proportioned to their services. ${ }^{, 33}$ Additionally, various French journals reported that the deputies sought officers for commission in the fledgling American army. For instance, in December of 1776, the Gazette de Leyde mentioned the search for officers by the American deputies. The journal reported that officers were being recruited and that the British government was aware of the activities of the Americans in France: "Viscount of Stormont, Ambassador of England, attested with displeasure that a man well known, and said to be employed by the Government in the secret commissions, has sometimes with Mr. Dean, Agent of the British Colonies, recruited these officers for the service of the Americans." ${ }^{34}$ Again, this proved problematic not only for France, which was trying to remain neutral, but also for America since Deane was not authorized to hand out these commissions - especially since he offered large quantities of money as well.

Unfortunately for Deane, the officers he sent to America failed to live up to expectations and, worse, sought to gain ranks above members of the Continental Army despite the appearance of being less qualified. One of these recruits, Philippe Charles

\footnotetext{
${ }^{33}$ Ségur, Memoirs and Recollections of Count Louis Philippe de Ségur, 103-104.

${ }^{34}$ Gazette de Leyde, 6 December 1776.
} 
Tronson du Coudray, was particularly disastrous since not only was he arrogant, he was also under qualified for the commission. The appointment of Tronson du Coudray to the position of Major General, a promotion above far more qualified colonial officers, harkened back to the era of the Seven Years War and colonial complaints of British Regulars holding exclusive rights to higher positions in the army based simply on the geographic location of their birth. ${ }^{35}$ These missteps gave Arthur Lee and his supporters the ammunition they needed to request Silas Deane's dismissal from France in order to answer the charges before the Continental Congress in 1778.

News of this scandal proved problematic for the French ministry who had publicly promoted an agreement with the American deputies. Anxious to protect this union between the two powers, Vergennes clearly articulated French support for both Silas Deane and Benjamin Franklin both the journals and his own private correspondence. Scholars have debated why Vergennes and others chose this position, but in order to make sense of the French ministry's reaction, it is important to remember the historical context discussed above and the impact of Deane and Franklin's popularity on the morale of the French reading public.

For practical reasons, Beaumarchais was troubled by the repercussions of the charges against Deane for war profiteering and misuse of funds. After all, Deane and the other deputies owed the Roderigue Hortalez Company great sums of money on the American government's behalf. Concerned these debts would never be paid if Deane was

\footnotetext{
${ }^{35}$ The uproar surrounding the commission offered to du Coudray by Deane resulted in threats by American officers to resign and fears of foreign recruits taking control of the American military force. Du Coudray died in late 1777, but the consequences of his appointment had lasting reverberations for Deane, and scholars often point to du Coudray's appointment in particular as one of Deane's largest missteps leading up to his eventual removal from diplomatic service in France. Du Coudray's letters depict a man full of aristocratic arrogance who lacks the diplomatic skills necessary to navigate a fraught political situation both in France and in America. See the Tronson du Coudray Papers, Special Collections Research Center, Swem Library, College of William and Mary.
} 
discredited, Beaumarchais turned to Vergennes, who in turn informed Louis XVI of the implications of the situation. ${ }^{36}$ Beaumarchais had already made his dislike for Arthur Lee known to Vergennes. In a December 7, 1777 letter to Vergennes, Beaumarchais wrote, "I have always made a great difference between the honest deputy Deane with whom I have had dealings, the insidious politician Lee and the taciturn Dr. Franklin."37 Vergennes assured both Louis XVI and Beaumarchais that he had confidence in Deane's veracity and expressed a growing dislike for Arthur Lee. ${ }^{38}$ Vergennes praised Silas Deane's “zeal, activity, and intelligence," saying Deane "has merited the esteem of the king, and for which his Majesty had been pleased to give him [Deane] marks of satisfaction." 39 Vergennes' letters to Arthur Lee, however, were often cold and dispassionate and a result of conferring with his fellow ministers rather than an open correspondence. ${ }^{40}$ In fact, many historians have noted that Lee was often considered highly confrontational and as a result, left out of both the partnership with Beaumarchais and a number of the other negotiations. $^{41}$

\footnotetext{
${ }^{36}$ More information about the implications of the Deane investigation for the Roderigue Hortalez Company can be found in the works of Dull, Murphy, Potts, James, and Perkins, as well as a number of other contributions to the extensive historiography relating to economics in the Age of Revolutions. For more on Beaumarchais' reaction and appeals to Vergennes, see Baron de Beaumarchais to the Comte de Vergennes, 12 March 1778, in B.F. Stevens's Facsimiles of Manuscripts in European Archives Relating to America, 1773-1383: With Descriptions, Editorial Notes, Collations, References and Translations (London: Photographed and Printed by Malby \& Sons, 1889-1895).

${ }^{37}$ Beaumarchais to Vergennes, 7 December 1777, quoted in Potts, Arthur Lee, 187. Facsimiles of the original French letter can be found in Facsimiles, no. 1763.

${ }^{38}$ See Perkins, France in the American Revolution, 221; James, Silas Deane, 57-60.

${ }^{39}$ Vergennes to the president of Congress, 25 March 1778, quoted in James, Silas Deane, 59.

${ }^{40}$ See, among others, Arthur Lee to the Comte de Vergennes, 17 April 1778; Comte de Vergennes to the American Commissioners, 29 April 1778; American Commissioners to the Comte de Vergennes, 19 May 1778; Comte de Vergennes to Monsieur de Sartine, 22 August 1778; and Arthur Lee to the Comte de Vergennes, 30 August 1778, all in Stevens, Facsimiles, Vol. 22, 389, 433, 455, 555, and 557 respectively.

${ }^{41}$ In particular, see Potts, Arthur Lee.
} 
Lee expressed his displeasure with this treatment most vociferously in his letters to family and friends back in America. ${ }^{42}$ In a February 9, 1778 letter to Francis Lightfoot, Lee bemoaned his observation that he had received only partial information from Franklin and Deane and declared "it was very difficult for me to be of any utility whatsoever in these negotiations." ${ }^{, 43}$ Perhaps even more damaging to Lee's reputation in France was the knowledge that Franklin found Lee insufferable and openly supported Deane instead. ${ }^{44}$ Since Franklin was so revered, his endorsement or lack thereof held additional weight. In fact, Franklin wrote to Francis Hopkinson, "[The enmity of Lee] I owe to the people of France, who happened to respect me too much and him too little which I could bear, and he could not." ${ }^{45}$

Moreover, Deane and his supporters were seen as more sympathetic to the French objectives in the war than was Lee. Especially after the signing of the Alliance, French government officials had reason to suppress discord. Vergennes saw the challenge to Deane as a sign that the anti-war factions were winning out in the Continental Congress and became concerned that America would look to make peace with England and that France would have to fight Britain alone. ${ }^{46}$ Additionally, historians such as Coy Hilton James argue that the decision to send Conrad A. Gérard, the foreign minster to America, on the same boat as Deane was a calculated move on the part of Vergennes to show French support for Deane rather than Lee. ${ }^{47}$

\footnotetext{
${ }^{42}$ Arthur Lee Letters, 1777-1780, Accession \#202, Special Collections Department, University of Virginia Library, Charlottesville, VA; and Arthur Lee Papers (MS Am811-811.7), Houghton Library, Harvard University.

${ }^{43}$ Arthur Lee to Francis Lightfoot, 9 February 1778, quoted in Potts, Arthur Lee, 194.

${ }^{44}$ See James, Silas Deane, 57-60.

${ }^{45}$ Benjamin Franklin to Francis Hopkinson, quoted in James, Silas Deane, 62.

${ }^{46}$ For more on this argument, see James, Silas Deane, 57-69; and Dull, A Diplomatic History of the American Revolution, 82-89.

${ }^{47}$ James, Silas Deane, 57-60.
} 
Yet, there is more to this story than what's been narrated thus far. Up to this point, this paper has focused primarily on French diplomats' perception of the three American deputies who resided in Paris at the start of the American War of Independence and the French government's response to the overtures for alliance, as well as the consequences of the eruption of discord surrounding Silas Deane. The actions of government officials are, however, only one factor important for understanding the historical implications of the Franco-American Alliance of 1778. Despite being ruled as an absolute monarchy, the French state had, by the latter half of the eighteenth century, become increasingly dependent on the goodwill of the public sphere. One way popular opinion could be shaped was through the press. Vergennes, Franklin, and others actively courted public support in various official and unofficial journals throughout France. ${ }^{48}$ As such, any discussion of the ramifications of the scandal surrounding the Franco-American Alliance must take into account an educated and active public who read newspapers on a regular basis and formed opinions based on what they read.

In considering the situation in America, many intellectuals and young members of the nobility sought to discover new incarnations of the historical memories that they held of both classical civilization and an ideal, heroic France. ${ }^{49}$ Furthermore, at the time of the

\footnotetext{
${ }^{48}$ This paper focuses on two state-promoted journals in France in 1778: the Gazette de France and the Affaires de l'Angleterre et de l'Amérique. Numerous other papers circulated in France at the time, including those published outside the borders of France in order to avoid censorship. However, most of these other journals (such as the Gazette de Amsterdam and the Gazette de Leyde) included similar articles and employed similar strategies to the official French newspapers. Not surprisingly, the journals published within the borders of France tended to be less critical of French government policies and avoided direct criticism of French practices. However, they still maintained some degree of autonomy, particularly with regard to foreign affairs, and should not be discounted as expressions of general elite opinion.

${ }^{49}$ This line of thinking has become increasingly popular in the past few years. See in particular Bell, The Cult of the Nation in France; Doina Pasca Harsanyi, Lessons from America: Liberal French Nobles in Exile, 1793-1798 (University Park: The Pennsylvania State University Press, 2010); Julia Osman, “Ancient Warriors on Modern Soil: French Military Reform and American Military Images in Eighteenth-Century France," French History 22, no. 2 (May 2008); Smith, The Culture of Merit; Lauren Wallace, "The
} 
American Revolution, Louis XVI enjoyed immense popularity, leading some historians to argue that since rebellion was not possible or conceivable in France, many young nobles of the sword who thirsted for violence and glory looked instead to the possibility of a rebellion in another locale. They sought to recreate instances of the just mercenary or the medieval chivalric knight. Ségur, for instance, asked, "How could the monarchical governments of Europe wonder at the enthusiasm for liberty which was manifested by young men of ardent minds, who were everywhere instructed to admire the heroes of Greece and Rome, before whom the most enthusiastic praise were bestowed upon the release of Switzerland and Holland from thralldom, and who were taught to read and to reflect by constantly studying the works of the most celebrated republicans of antiquity?" ${ }^{50}$ Vergennes and even Franklin himself exploited this obsession. Simon Schama argues that Lafayette and others saw the American Revolution as the embodiment of the virtue and glory that the Old World seemed incapable of recreating. ${ }^{51}$ Frequently, the intellectual elite projected its ideal society onto America, ${ }^{52}$ something Vergennes and others were quick to capitalize on in the portrayal of America in Frenchlanguage gazettes. ${ }^{53}$

While traditional diplomatic historians such as Jonathan Dull downplay the impact of newspapers and political culture on diplomacy, recent scholarship has rendered

Revolutionary Career of Louis Philippe de Ségur: Caught Between Tradition and Reform" (MA Thesis, the College of William and Mary, 2013).

${ }^{50}$ Ségur, Memoirs and Recollections, 76.

${ }^{51}$ Schama, Citizens, 27.

${ }_{53}^{53}$ Palmer, The Age of the Democratic Revolution, 253.

${ }^{53}$ Julia Osman has written extensively about the portrayal of American soldiers in French newspapers, arguing that the emphasis on classical thought and history in the French education system led to the French educated public's perception of the American colonists as the embodiment of this classical ethos. For more on this subject, see Julia Osman, "Ancient Warriors on Modern Soil," 175 - 196. See also, Wallace, "The Revolutionary Career of Louis Philippe de Ségur," and Doina Pasca Harsanyi, Lessons from America. 
this position untenable. ${ }^{54}$ The work of print culture historians, such as Jack Censer, Robert Darnton, Daniel Roche, and Jeremy Popkin, on the French press in the late eighteenth century suggests the proto-public sphere was more extensive than previously acknowledged. Roger Chartier, for instance, argues the development of a coherent public sphere and a culture of communication was largely a result of print media and the publishing industry. ${ }^{55}$ Keith Baker meanwhile reminds scholars that "public opinion" is a fraught term, but can be defined in relation to efforts to mobilize the opinion of the educated and literate in favor of a government position through control of the publication and circulation of journals. ${ }^{56}$ For the purposes of this analysis, public opinion remains a useful term, but with the caveat that the definition remains fluid and subject to the historical context. In this case, public opinion refers to state efforts to mobilize the educated elite in support of the American cause. Journals are not direct reflections of the opinions of a vast populous, but instead - even in conditions of censorship - function as the stimulus for larger discussions of policy. ${ }^{57}$ Vergennes sought to harness this power through the crafting of newspapers as propaganda. ${ }^{58}$

\footnotetext{
${ }^{54}$ For Dull's opinion of the press in early modern diplomacy, see Dull, A Diplomatic History of the American Revolution, 67.

${ }^{55}$ Roger Chartier, The Cultural Origins of the French Revolution, 32.

${ }^{56}$ Keith Michael Baker, "Politics and Public Opinion Under the Old Regime," in Press and Politics in PreRevolutionary France, ed. Jack R. Censer and Jeremy D. Popkin (Berkeley: University of California Press, 1987), 214.

${ }^{57}$ With the onset of the French Revolution and the explosion of an uncensored press, journalism became the mouthpiece of "the people" rather than the government. However, at the time of the American Revolution, public expression in the press remained extremely limited due to strict controls over the right to publication. Generally, journals refrained from direct criticism of the French government, but editors had some autonomy with regard to reports from elsewhere in the Atlantic. Censors largely focused their attention on domestic rather than international concerns, so despite the fact that there was no such thing as freedom of the press in pre-revolutionary France, journals should not be discounted as a source of information about public, albeit a severely limited definition of public, opinion. For more on this phenomenon see Popkin, Revolutionary News, chapters 1-2.

${ }^{58}$ The French press was more positive while Vergennes in power, perhaps because much of reading public also saw French involvement in America as a good thing. Obviously, state-sponsored periodicals were even more favorable to the American cause than those published outside the borders of France. See Censer, The French Press in the Age of Enlightenment, 207.
} 
First, analysis of the public sphere and early modern public opinion requires an understanding of the demographic makeup of the educated elite targeted by journalists and their patrons such as Vergennes. The reading of newspapers was a distinctly elite activity pursued primarily by the nobility and upper bourgeoisie. Since the price of a subscription to the Gazette de France was twelve livres a year, the average laborer just simply did not have the capital available to purchase a regular subscription, and especially not subscriptions to multiple papers. ${ }^{59}$ Of the 199 known subscribers to the Gazette de France, about 113 were noble or about $57 \%$ of the total number of subscriptions. ${ }^{60}$ Merchants, government officials, and other members of the upper echelons of the Third Estate composed the bulk of the remainder of the readership. ${ }^{61}$ Despite the growing literacy rate, individuals or "the masses" on the street were not the target audience for these journals. There were probably some members of the "working poor" among the subscribers, and occasionally people did pool their resources in order to acquire a subscription, but this was the exception rather than the rule. ${ }^{62}$ Due to the high price of a subscription, many readers, including those of higher social and financial standing, would also frequent reading rooms where the proprietor would obtain a large quantity of domestic and foreign papers and where papers were read aloud. ${ }^{63}$ Urban

\footnotetext{
${ }^{59}$ Popkin, Revolutionary News, 22.

${ }^{60}$ Those not of noble status were usually involved in finance or other professions and can be classified as part of the upper echelons of the Third Estate. See Censer, The French Press in the Age of Enlightenment, 186-189.

${ }^{61}$ Newspapers are also related to a burgeoning salon culture that emerged during the eighteenth century. Wealthy women would host salons where leading philosophes would gather with the elite (both the nobility and the upper tier of the Third Estate ) to discuss new intellectual endeavors as well as current events. In addition to frequenting these salons, the American deputies often entertained at their own residences, where the elites of Paris sought additional information about American-French relations and American life. Ségur recalled that "the most distinguished individuals of the capital and the court, the most celebrated philosophers, scholars, and men of letters, daily frequented [the American deputies'] habitations." Ségur, Memoirs and Recollections, 103.

${ }^{62}$ Censer, The French Press in the Age of Enlightenment, 187.

${ }^{63}$ Palmer, The Age of the Democratic Revolution, 242-245.
} 
France was a very literate society for its moment, so publicizing the war could be successfully pursued via print media. ${ }^{64}$

As a government-approved journal, the Gazette de France reflected Vergennes' and other influential government officials' position on the American War and the French Alliance. While supportive of the American war effort from the beginning of the rebellion, much like Louis XVI himself, the editors carefully used vague and subtle rhetoric to avoid openly courting the outbreak of hostilities between France and England. ${ }^{65}$ This message must have reached a substantial number of readers since the Gazette de France had the highest subscription rates in the 1770 s of any journal in France. ${ }^{66}$ Additionally, the growth of reading rooms and the pooling of resources suggests a higher readership rate than strict numerical analysis would support. Despite censorship, official journals remained a lively forum and an important factor in the shaping of public opinion. ${ }^{67}$ As Censer and Popkin wrote, journals "played a central role in intellectual life" in eighteenth-century France. ${ }^{68}$

Like the Gazette de France, the Affaires de l'Angléterre et de l'Amérique was published in France and firmly under the control of the government. In fact, twentiethcentury research has revealed that the French government, and Vergennes in particular, actively supported its publication too. ${ }^{69}$ The Affaires de l'Angleterre et de l'Amérique

\footnotetext{
${ }^{64}$ See in particular Dull, A Diplomatic History of the American Revolution, 66.

${ }^{65}$ This strategy was common in print culture in the eighteenth century, as revolutionaries sought protection from censors or governments sought to hedge their bets. See Lauren Wallace, "Mobilizing Revolutionaries: Case Studies in Journalistic Radicalism from Eighteenth-Century France and America" (Honors Thesis, the University of North Carolina at Chapel Hill, 2011).

${ }^{66}$ For a detailed accounting of subscription rates during the Old Regime, see Censer, The French Press in the Age of Enlightenment.

${ }^{67}$ Jack R. Censer and Jeremy D. Popkin, Press and Politics in Pre-Revolutionary France, 11.

${ }^{68}$ Censer and Popkin, Press and Politics in Pre-Revolutionary France, 17.

${ }^{69}$ The support of Vergennes and others of the French government is widely accepted in current scholarship, particularly that undertaken in response to the bicentennial celebrations of the French Revolution. This
} 
also advocated support for the American cause through letters, copies of official documents, and other commentaries, such as the writings of American leaders. ${ }^{70}$ As with other newspapers at the time, many of these "articles" were borrowed from other foreign and domestic papers or relied on submissions by active intellectuals. Franklin himself often contributed to the publication. ${ }^{71}$ Additionally, the various remaining copies of the Affaires de l'Angleterre et de l'Amérique available in contemporary archives and libraries provide confirmation that American deputies and diplomats, as well as French officials, subscribed to and contributed to the journal.

As early as 1775 , French intellectuals began clamoring for information about the increasing hostilities between Britain and her colonies, prompting editors, and by extension concerned French ministers, to adopt certain strategies of reporting. As previously alluded to, the reading public of France grew increasingly concerned with rights and liberties towards the end of the eighteenth century, in part as a result of the new educational initiatives and attention to reason promoted by Enlightenment thinkers. In an effort to foster sympathy with their American counterparts, the editors of French journals consistently referenced the desires of the American rebels to counteract violations of their perceived natural rights. An April 10, 1775 edition of the Gazette de France, for instance, reported "the assembly of the committees of the province of Philadelphia, held the $28^{\text {th }}$ of last month, concerning the lead and measures of the general

scholarship includes detailed analysis of subscription rates and authorship associated with the French press in the second half of the eighteenth century; see, for example, Censer, The French Press in the Age of Enlightenment and Popkin, Revolutionary News.

${ }^{70}$ For more information about the types of documents featured in Affaires de l'Angleterre et de l'Amérique and its placement in broader Europe-wide developments, see Palmer, The Age of the Democratic Revolution, 249.

${ }^{71}$ For more on Franklin's contributions to Affaires de l'Angleterre et de l'Amérique, see Palmer, The Age of the Democratic Revolution, 250; and Dull, A Diplomatic History of the American Revolution, 79. 
Congress for the conservation of rights and liberties of the English colonies." ${ }^{, 72}$

Additional reporting from 1775 in the Gazette de France focused on colonial troop movements and highlighted the perceived strengths of the Americans as they sought to take on the British, as well as the general failings of the British parliament to appease the American insurgents effectively. ${ }^{73}$ These same strategies continued throughout the period leading up to the signing of the treaties in 1778. In August of 1776, for instance, another popular paper, the Gazette de Leyde, published numerous resolutions from many different colonies so French readers could become intimately acquainted with the various infractions of Great Britain towards her colonies. The August 30 edition of the paper included a full translation of the Declaration of Independence, as well as letters written by John Hancock and George Washington. ${ }^{74}$ The Affaires de l'Angleterre et de l'Amérique also routinely published full translations of American declarations, resolves, and constitutions, as well as letters written by leading American statesmen and intellectuals.

One of the rhetorical techniques often employed in the French journals was the glorification of a just cause. Prior to the signing of the treaties and ensuing scandal, in a February 8, 1778 printing of a letter between a banker of London and a gentleman of Antwerp, the anonymous author wrote, "To say nothing of the satisfaction just souls must have in reflection... who are opposed to tyranny and support the cause of liberty that is the cause of all good governments, since there is nothing good in those in which slavery

\footnotetext{
${ }^{72}$ Gazette de France, 10 April 1775.

${ }^{73}$ See, for instance, Gazette de France, 16 January 1775, 24 February 1775, 10 March 1775, and 13 March 1775.

${ }^{74}$ Gazette de Leyde, 30 August 1776.
} 
is the principle. ${ }^{, 75}$ Here, a discussion of the consequences of tyranny and the appropriate response of the "just soul" underscored the necessity of a glorious cause to garner support. Vergennes and his fellow ministers may have truly believed in the American cause, but they were also masters of manipulation, tapping into existing intellectual currents and a broader desire to put a newfound sense of purpose into action. The restrictive nature of an absolute monarchy, coupled with the rationalizing and mobilizing principles promoted by the Enlightenment, fostered within the French intellectual elite a desire to feel integral to the decision making process and a longing to recapture the glory of France. This impulse towards action among these intellectuals provided a base upon which Vergennes could, and did, mobilize men in support of policy.

Although signed in February of 1778, the Treaty of Amity and Commerce was not announced in the French press until April of $1778 .{ }^{76}$ In the journal secretly sponsored by Vergennes, the Affaires de l'Angleterre et de l'Amérique, the entirety of the agreement was printed in October of 1778 so readers could become acquainted with the new relationship between France and America. In the pages of this journal, this treaty joined a host of other government documents, including the Constitution of South Carolina, published earlier in 1778 , suggesting a long running rhetorical strategy. ${ }^{77}$ The French reading public hungered for the official documentation of various legal and constitutional agreements in part because of the growing fascination with the rights of man. In building support for the new alliance, Vergennes and other ministers were quick to capitalize on this interest to paint involvement in America as part of the trend towards greater

\footnotetext{
${ }^{75}$ Affaires de l'Angleterre et de l'Amérique, Volume 8.

${ }^{77}$ Dull, A Diplomatic History of the American Revolution, 98.

${ }^{77}$ Affaires de l'Angleterre et de l'Amérique, Volume 9.
} 
protection of perceived natural rights. Although the disgrace of Silas Deane was reported in the French press, news of the alliance and mobilization of troops dominated.

Thus, while certainly alarming, the recall of Silas Deane did not force a reevaluation of French perceptions of the American struggle and necessitated only slight modification of existing rhetorical strategies. The tactics that Vergennes employed to counteract the potential scandal surrounding Deane's removal from Paris were extensions of earlier projects of mobilization in which he highlighted the greatness of France and the "just" nature of the war effort. Rather than acknowledging trouble, articles immediately following Deane's removal from Paris continued to stress the relative weakness of the British government and comparative British inferiority to the French monarch. For instance, in an article published in the March 6, 1778 edition of the Gazette de France, the magnanimity of Louis XVI was contrasted to the duplicity of George III through a discussion of the social contract and the duties of a legitimate and enlightened government. The Gazette de France reported, "Our Majesty, in consequence of the protection of the stated duty to those subjects who devote their talents and their fortune to the state, it is determined to grant the request made to him... to erect the royal manufactory of fire arms he owed [the city of Tulle], and whose principal object, from its origin, ... [is] the armament of the troops of the marine service and the colonies. ${ }^{, 78}$ Here, Louis XVI was shown honoring his commitments and promises to his subjects, while George III was revealed to have no control over his own. In fact, despite promises to enforce "only those laws necessary for the regulation of commerce" in exchange for any rebellious colony's rejoining of the empire, the conclusion of the report on the activities of George III and his parliament notes, "the armament will continue by sea and land with

\footnotetext{
${ }^{78}$ Gazette de France, 6 March 1778.
} 
the same activity."79 The same applied to "the Kings Ordinance for the extension of the commissions of sailors in the royal navy from the $28^{\text {th }}$ of this month [March] to the next $30^{\text {th }}$ of April." 80 The article interpreted domestic and foreign affairs in such a way as to cast the French king in a favorable light and indicate that the American War of Independence was to be fought all for the glory of France. ${ }^{81}$

The Affaires de l'Angleterre et de l'Amérique followed a similar strategy to the Gazette de France in its handling of the potential scandal surrounding Deane. For instance, under the heading of "From a Banker of London to $\mathrm{M}^{* * *}$ in Antwerp" dated October 10, 1778, an anonymous author depicted the continued triumphs of the American militias over seemingly superior British troops and generals. The letter reported that despite Great Britain's perceived sense of superiority, “the Congress [in Philadelphia], by its wisdom and virtue, triumphed with all the art of an enchanter, as the American militias, with their bravery and their consistency, aborted the best war plans created by the ablest British Generals." 82 This maintenance of earlier rhetorical strategies, which highlighted the virtue and bravery of the Americans, was intended to underline France's continued dedication to the war effort. Despite private fears concerning ongoing American commitment to the cause, Vergennes, as an experienced statesman, knew that the longer battle for morale could be won in the newspapers.

Another example of this strategy can be seen in the December 29, 1778 edition of the Gazette de France. The editors of the journal carefully and consciously manipulated the record of a meeting of the British Parliament to suggest that the British educated elite

\footnotetext{
${ }^{79}$ Gazette de France, 6 March 1778.

${ }^{80}$ Gazette de France, 6 March 1778.

${ }^{81}$ Censer, The French Press in the Age of Enlightenment, 207.

${ }^{82}$ Affaires de l'Angleterre et de l'Amérique, Volume 13.
} 
- the contemporaries of the journal's own reading public - expressed serious doubts

about the feasibility and moral implications of continuing the war with America.

Contrasted with the French government's fear of a weakening of American resolve as a

result of the Silas Deane affaire, the rhetorical strategy employed in the December 29

edition becomes all the more poignant. The French reading public could be assured of a

righteous and deserved victory, and Vergennes could effectively and covertly shift

attention away from America and growing ministerial fears that Deane's recall meant a

lessening of support in America and instead, focus the reader on a weakening Great

Britain. ${ }^{83}$ According to the editors, Edmund Burke had remarked, "I will agree that it is

not expedient to continue the war in America where all our projects have so often

failed.... What astonishes me, he added, is the serious discussion here to recognize or not

the independence, as if it were a choice, instead of pure necessity." ${ }^{\circ 4}$

Additionally, the editors of the December 29 edition of the Gazette de France

made certain to highlight the importance of the Franco-American Alliance by claiming

that the great statesman Burke felt the alliance both necessary and inevitable. "He

astonished the opposition party even more when he declared that nothing had been so

\footnotetext{
${ }^{83}$ Throughout the closing years of the early modern period, many Europeans became concerned with what they perceived to be the declining morality of their epoch. This trend can be traced back to the idea of the Black Legend in Spanish America. But as a result of the scramble for India and the spread of slavery, many European powers, including Great Britain, began in the latter half of the eighteenth century to enact policies and craft new law codes aimed at protecting imperial interests while projecting benevolence and moral certitude. This is particularly true with regard to slavery and the brutal atrocities committed by the East India Company in Asia. By the late eighteenth century, European intellectuals and policy makers, especially in Britain, had embarked on a campaign of assigning blame, suggesting colonials existed in a state of what Richard Dunn refers to as social failure. This, in turn, created an atmosphere in which European powers began to compete to be considered more moral than their contemporaries in their military actions and in their laws. As a result of this new focus on morality, countries like France required victories not only to be achievable, but also justifiable as a response to incidents of perceived immorality or failure to protect the interests of colonial dependents. See Christopher Brown, Moral Capital: Foundations of British Abolitionism, (Chapel Hill: University of North Carolina Press, 2006); Richard Dunn, Sugar and Slaves; and Jack P. Greene, Evaluating Empire and Confronting Colonialism in Colonial British America (Cambridge: Cambridge University Press, 2013).

${ }^{84}$ Gazette de France, 29 December 1778.
} 
natural as an alliance of the Americans with the French," because the refusal of Parliament to address the grievances of and recognize the rights of the Americans drove them to independence in the first place. ${ }^{85}$ Instead of dwelling on the implications of Silas Deane's recall to America, the moral of story here is that the war was Great Britain's fault for not operating according to its own stated principles.

The contrast between Britain and America in the Gazette de France and the Affaires de l'Angleterre et de l'Amérique throughout the late 1770s was part of a larger, long-running strategy on the part of editors and the French ministry of reimagining the historical memory of France. For instance, memories of the Ligue and the Fronde were used to inspire young nobles to support the American Revolution in an effort to recapture the old glory of France ${ }^{86}$ Additionally, other historians have highlighted the creation of a new canon of Great Frenchmen in the eighteenth-century educational system. ${ }^{87}$ The newspapers published by the French monarchy in 1778 were an extension of this historicizing impulse and were designed to help the educated elite contextualize and make sense of the rebellion half a world away as well as legitimize their own involvement.

The government and the public may have had different motivations in their initial support for the American independence movement, but this paper has argued that Vergennes and the American deputies in France were actively involved with the written culture of the time and aware of the power of this growing public sphere. The American War of Independence, as experienced in France, represented a period of increased French involvement in domestic and foreign affairs at the educated elite level of society. Many

\footnotetext{
${ }^{85}$ Gazette de France, 29 December 1778.

${ }^{86}$ Ségur, Memoirs and Recollections of Count Louis Philippe de Ségur, 20 and 76.

${ }^{87}$ See Bell, The Cult of the Nation in France, and Smith, Nobility Reimagined.
} 
elites wanted to feel useful and tested out how they might influence policy - something Vergennes and others enthusiastically exploited to garner support for their own agendas.

Throughout the war, Vergennes used the print media as a vehicle for acquiring support for state aspirations and policies through careful manipulation of and emotional appeals to elite desires. The widespread use of print media represented an acknowledgement by Vergennes that the French government needed the support of the public, particularly powerful intellectuals and the nobility, to engage in military conflict. It is also indicative of the growing popularity of the American deputies and statesmen, as well as the shifting nature of propaganda. Since the American deputies were so successful at cultivating positive public opinion, Vergennes and the French government adopted new strategies of manipulation, including the use of government controlled newspapers to capitalize on this positive public image in an effort to achieve their own goals of favorable balances of power and trade.

The recall of Silas Deane to America following the signing of the treaties of Amity and Commerce had the potential of becoming a truly disastrous situation, quite likely derailing the entire French propaganda machine carefully cultivated by Vergennes. However, rather than a drastic shift in the coverage of America in the journals, Vergennes and his editors maintained existing methods of mobilization to combat a possible collapse in morale. Instead of panic and reevaluation, editors employed consistent rhetorical strategies, although after March of 1778 the focus of the articles shifted from descriptions of the noble and virtuous actions of the Americans to the dishonorable actions of the British. Before, Britain was often painted in a negative light, but the articles referenced and highlighted American responses. After Silas Deane was recalled, the journals tended 
to embark on comparisons between Britain and France, glorifying the French war effort and the French state. By only slightly altering the rhetorical strategy, Vergennes manipulated the reading public into believing that the scandal was irrelevant and assured readers that French policy would remain unchanged as it was the correct course of action.

At its core, the story of the treaties of Amity and Commerce is part of a larger narrative of French engagement with both the growing public sphere and the increasingly interconnected Atlantic World during the War of American Independence. This paper has explored the events leading up to and immediately following the signing of the treaties of Amity and Commerce through the eyes of the French ministry, the American deputies stationed in France, and the budding educated French reading public. Each segment of the larger conglomeration of interested parties had its own distinct motivations for involvement, but nonetheless actively pursued and promoted French engagement in America using similar strategies for mobilization. Generally, the French government was interested in promoting the war effort to acquire financial and political benefits for the state, while the public was encouraged to be interested in glorifying itself and France through a noble cause. Despite this disconnect, there is no denying that the discussions of the War of American Independence represented the beginnings of a merging of disparate opinions, concerns, and motivations into the enacting of a single state policy.

Ultimately, despite the potential for a disastrous public disillusionment with the American cause following the recall of Silas Deane to face charges of corruption, the reading public remained committed to the war effort because French journals continued to stress the concerns of intellectuals rather than the fears of the French ministry or the infighting between the American deputies. Excitement over the possibility of aiding the 
Americans reached a fever pitch in 1778 with the official entry of France into the war. Arthur Lee himself rightly remarked, "There is not a part of the world upon which France looks with a more attentive eye than upon America. There is not the smallest event, relative to our proceedings towards the colonies of which they are not minutely informed. ${ }^{, 88}$ While this French public sphere remained enthralled with the new American state, scandals, fears, and motivations of ministers and deputies necessarily remained a footnote in a larger narrative of French power and moral certitude.

${ }^{88}$ Arthur Lee to Richard Henry Lee, 18 March 1774, quoted in Potts, Arthur Lee, 148. 


\section{Works Cited:}

Newspapers:

La Gazette de France

La Gazette de Leyde

Les Affaires de l'Angleterre et de l'Amérique

Papers Collections and Published Primary Sources:

Arthur Lee Letters, 1777-1780, Accession \#202, Special Collections Department, University of Virginia Library, Charlottesville, VA.

Arthur Lee Papers (MS Am811-811.7), Houghton Library, Harvard University.

Deane, Silas. The Deane Papers, 1774 to 1790. New York: New York Historical Society, 1887.

Louis XVI, King of France. Correspondence. Louis XVI and the comte de Vergennes: Correspondence 1774-1787. Ed. Hardman, John and Munro Price. Oxford: Voltaire Foundation, 1998.

Louis XVI, King of France. "Réflexions." In The Marquis de La Fayette in the American Revolution, with some account of the attitude of France toward the War of Independence Volume 1. Ed. Tower, Charlemagne. Freeport: Books for Libraries Press, 1971.

Ségur, Louis Philippe de. Memoirs and Recollections of Count Louis Philippe de Ségur: Three Volumes in One. Ed. Tupper, Harmon and Harry W. Nerhood. New York: Arno Press \& The New York Times, 1970.

Stevens, Benjamin Franklin. B.F. Steven's Facsimiles of Manuscripts in European Archives Relating to America, 1773-1383: With Descriptions, Editorial Notes, Collations, References and Translations. London: Photographed and Printed by Malby \& Sons, 1889-1895.

Tronson du Coudray Papers, Special Collections Research Center, Swem Library, College of William and Mary.

\section{Secondary Sources:}

Armitage, David. The Declaration of Independence: A Global History. Cambridge, MA and London: Harvard University Press, 2007.

Baker, Keith Michael. "Introduction: On the Problem of the Ideological Origins of the French Revolution." In Inventing the French Revolution: Essays on French Political Culture in the Eighteenth Century. New York: Cambridge University Press, 1990. 
Baker, Keith Michael. "Politics and Public Opinion Under the Old Regime." In Press and Politics in Pre-Revolutionary France. Ed. Censer, Jack R. and Jeremy D. Popkin. Berkeley and Los Angeles: University of California Press, 1987.

Bell, David A. The Cult of the Nation in France: Inventing Nationalism, 1680-1800. Cambridge, MA and London: Harvard University Press, 2001.

Black, Jeremy. America or Europe?: British Foreign Policy, 1739-63. London and Bristol: UCL Press, 1998.

Censer, Jack R. The French Press in the Age of Enlightenment. London and New York: Routledge, 1994.

Censer, Jack R. and Daniel Roche, Eds. Press and Politics in Pre-Revolutionary France. Berkeley: University of California Press, 1987.

Chartier, Roger. The Cultural Origins of the French Revolution. Trans. Lydia Cochrane . Durham and London: Duke University Press, 1991.

Chaussinand-Nogaret, Guy. The French Nobility in the Eighteenth Century. Trans. William Doyle. Cambridge, London, New York and Melbourne: Cambridge University Press, 1985.

Collins, James B. The State in Early Modern France. Cambridge: Cambridge University Press, 1995.

Darnton, Robert. The Great Cat Massacre and Other Episodes in French Cultural History. New York: Basic Books, 1984.

Darnton, Robert. The Literary Underground of the Old Regime. Cambridge, MA and London: Harvard University Press, 1982.

Darnton, Robert and Daniel Roche, Eds. Revolution in Print: The Press in France 17751800. Berkeley, Los Angeles, and London: University of California Press, 1989.

Dewar, Helen. "Canada or Guadeloupe?: French Perceptions of Empire, 1760-1763." Canadian Historical Review 91, no. 4 (December 2010).

Doyle, William. Aristocracy and its Enemies in the Age of Revolution. New York: Oxford University Press, 2009.

Doyle, William. The French Revolution: A Very Short Introduction. Oxford: Oxford University Press, 2001. 
Doyle, William. Officers, Nobles and Revolutionaries: Essays on Eighteenth-Century France. London and Rio Grande: The Hambledon Press, 1995.

Doyle, William. Origins of the French Revolution, Second Edition. Oxford: Oxford University Press, 1989.

Dull, Jonathan R. A Diplomatic History of the American Revolution. New Haven and London: Yale University Press, 1985.

Dunn, Richard. Sugar and Slaves: The Rise of the Planter Class in the English West Indies, 1624-1713. Chapel Hill: The University of North Carolina Press, 1972.

Forrest, Alan. "Enlightenment, Science, and Army Reform in Eighteenth-Century France." In Enlightenment and Revolution: Essays in Honour of Norman Hampson. Eds. Malcolm Crook, William Doyle, and Alan Forrest. Hampshire and Burlington: Ashgate Publishing, 2004.

Gottschalk, Louis. Lafayette Comes to America. Chicago: The University of Chicago Press, 1935.

Gottschalk, Louis. The Era of the French Revolution (1715-1815). Boston, New York, Chicago, Dallas, and San Francisco: Houghton Mifflin Company, 1929.

Gottschalk, Louis and Donald Lach. Toward the French Revolution: Europe and America in the Eighteenth-Century World. New York: Charles Scribner's Sons, 1973.

Green, Jack P. and Philip D Morgan. Atlantic History: A Critical Appraisal. Oxford and New York: Oxford University Press, 2009.

Grieder, Josephine. Anglomania in France, 1740-1789: Fact, Fiction, and Political Discourse. Geneva: Librairie Droz, 1985.

Harsanyi, Doina Pasca. Lessons from America: Liberal French Nobles in Exile, 17931798. University Park, PA: The Pennsylvania State University Press, 2010.

Higonnet, Patrice. Class, Ideology, and the Rights of Nobles During the French Revolution. Oxford: Clarendon Press, 1981.

Hoffman, Ronald and Peter J. Albert, Eds. Diplomacy and Revolution: The FrancoAmerican Alliance of 1778. Charlottesville: University Press of Virginia, 1981.

Hunt, Lynn. Politics, Culture, and Class in the French Revolution. Berkley and Los Angeles: University of California Press, 1984.

James, Coy Hilton. Silas Deane - Patriot or Traitor? East Lansing: Michigan State University Press, 1975. 
Klooster, Wim. Revolutions in the Atlantic World: A Comparative History. New York: New York University Press, 2009.

Kramer, Lloyd. Lafayette in Two Worlds: Public Cultures and Personal Identities in an Age of Revolutions. Chapel Hill and London: The University of North Carolina, 1996.

Kupperman, Karen Ordahl. The Atlantic in World History. Oxford and New York: Oxford University Press, 2012.

Lefebvre, Georges. The French Revolution from its Origins to 1793. Trans. Elizabeth Moss Evanson. New York: Columbia University Press, 1962.

Murphy, Orville T. Charles Gravier Comte de Vergennes: French Diplomacy in the Age of Revolution, 1719-1787. Albany: State University of New York Press, 1982.

Osman, Julia. "Ancient Warriors on Modern Soil: French Military Reform and American Military Images in Eighteenth-Century France." French History 22, no. 2 (June 2008).

Palmer, R. R. The Age of the Democratic Revolution: A Political History of Europe and America, 1760-1800. Volume I: The Challenge. Princeton: Princeton University Press, 1959.

Perkins, James Breck. France in the American Revolution. Boston and New York: Houghton Mifflin Company, 1911.

Popkin, Jeremy D. A Short History of the French Revolution, Fifth Edition. Upper Saddle River, NJ: Prentice Hall, 2010.

Popkin, Jeremy D. Revolutionary News: The Press in France 1789-1799. Durham and London: Duke University Press, 1990.

Popkin, Jeremy D. and Bernadette Fort, Eds. The Mémoires Secrets and the Culture of Publicity in Eighteenth-Century France. Oxford: Voltaire Foundation, 1998.

Potts, Louis W. Arthur Lee: A Virtuous Revolutionary. Baton Rouge and London: Louisiana State University Press, 1981.

Schama, Simon. Citizens: A Chronicle of the French Revolution. New York: Alfred A. Knopf, 1989.

Smith, Jay M. The Culture of Merit: Nobility, Royal Service, and the Making of Absolute Monarchy in France, 1600-1789. Ann Arbor: The University of Michigan Press, 1996. 
Smith, Jay M. The French Nobility in the Eighteenth Century: Reassessments and New Approaches. University Park, PA: The Pennsylvania State University Press, 2006.

Smith, Jay M. Nobility Reimagined: The Patriotic Nation in Eighteenth-Century France. Ithaca and London: Cornell University Press, 2005.

Thornton, John K. A Cultural History of the Atlantic World, 1250-1820. Cambridge and New York: Cambridge University Press, 2012. 